症例

Recklinghausen 病を合併し家族性腺腫性ポリポーシスの 大腸・直腸全摘術後に発生したデスモイド腫瘍の 1 例

\begin{tabular}{ccc}
\multicolumn{8}{c}{ 金沢赤十字病院外科, 同 放射線科* } \\
大堀 & 功 佐々木 & 誠 宮 下 知 治 \\
浅 野 & 健 木 本 達 哉* &
\end{tabular}

症例は26歳女性, 幼少時よりカフェ・オ・レ斑を認め, 高校時代に皮骨生検にて Recklinghausen 病 (NF 1) と診断された. 24歳時に家族性腺腫性ポリポーシス (FAP) と診 断され, 結腸全摘・直腸粘膜抜去・回腸 $\mathrm{J}$ パウチ肛門吻合術を受けた. 術後 2 年の CT 検 査で, 腹壁に 2 個の腫湯が指摘された. MRI 検查にて, 頭尾側方向へ浸潤を示す腫場の 所見が得られた。生検にてデスモイド腫場と診断後, 腫瘍を摘出した. NF 1 と FAPは ともに癌抑制遺伝子の異常を基盤とする常染色体優性遺伝を示す疾患である. 発生頻度 は各々, 3 千から 4 千分の 1,8 千から 2 万 4 千分の 1 であり, 両疾患の合併は 2 千 3 百万から 7 千百万分の 1 と推測されているが, 両者が併存した報告は世界で 1 例である. さらに，デスモイド腫潢を合併した症例を経験したので，文献的考察を加え報告した。

索引用語：familial adenomatous polyposis, von Recklinghausen's disease, desmoid tumor

\section{緒 言}

Recklinghausen 病 (NF 1) と家族性腺腫性ポリポ ーシス (FAP) はともに癌抑制遺伝子の異常を基盤と する常染色体優性遺伝を示す疾患であり, 発生頻度は 各々， 3 千から 4 千分の 1,8 千加 2 万 4 千分の 1 であり，いずれも稀な疾患である。また両疾患の合併 の頻度は，2千 3 百万から 7 千百万分の 1 と推測され ているが，その報告は世界でわずか 1 例である1). 一 方, デスモイド腫瘍は筋や筋膜から発生する腫場だが, FAPの約 $100 \%$ に合併して発生を認めることから APC 遺伝子との関連が示唆されている21. 今回, われ われはNF 1，FAP およびデスモイド腫瘍を合併した 症例を経験したので文献的考察を加え報告する。

\section{症 例}

症例：26歳, 女性.

既往歴：幼少時からカフェ・オ・レ斑を認め, 高校 時代に皮周生検にて Recklinghausen病と診断され た.24歳時に家族性腺腫性ポリポーシス (FAP) と診

2001 年 4 月 2 日受付 2001 年 8 月 1 日採用

〈所属施設住所〉

厂921-8162 金沢市三馬 2-251
断され，当科にて結腸全摘・直腸粘膜抜去・回腸 $\mathrm{J}$ パ ウチ肛門吻合術 (IAA) を施行された. 非密生型で癌 の合併はなく, APC 遺伝子検査では exon 15 (codon 658〜1,283）に異常（図 1）が認められた.

家族歴：父と姉が非密生型 FAP. 父は IAA 未施行 で56歳時に癌合併死した。姉は26歳時に IAA 施行され

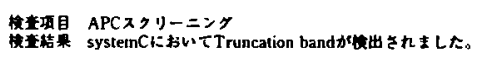
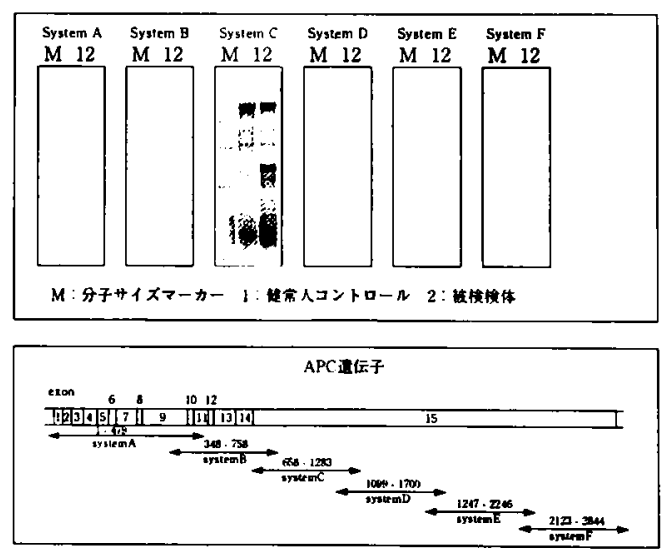

図 1 APC 遗伝子検査：exon 15 (codon 658 1,283）において異常が認められた。 


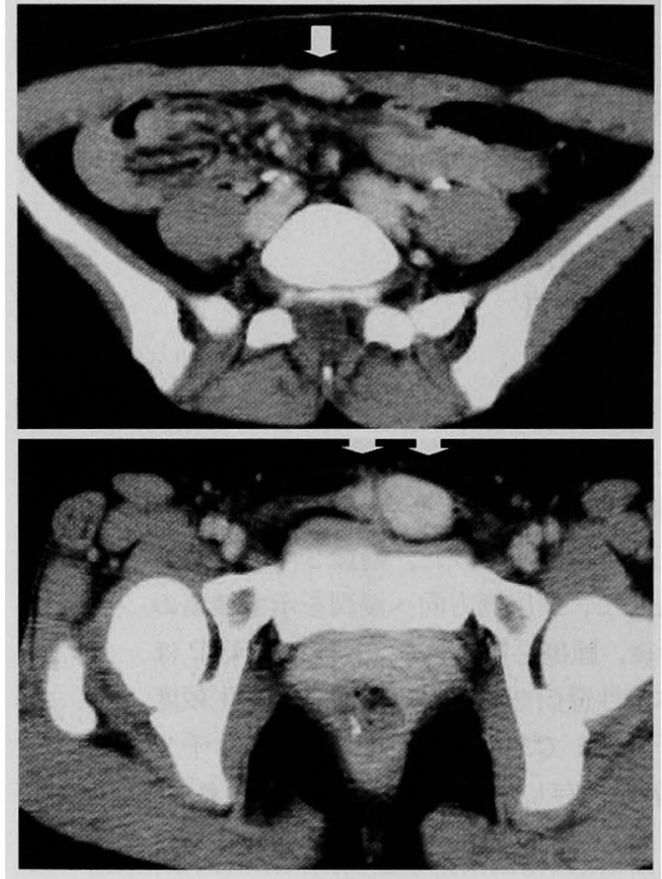

図 2 CT 検查 (術後 2 年)：上) 腹壁正中臍下部に約 $2 \mathrm{~cm}$ 大のよく染まる腫瘍（矢印）を認める，下） 恥骨上前方に約 $4 \mathrm{~cm}$ 大のよく染まる腫演（矢印） を認める。

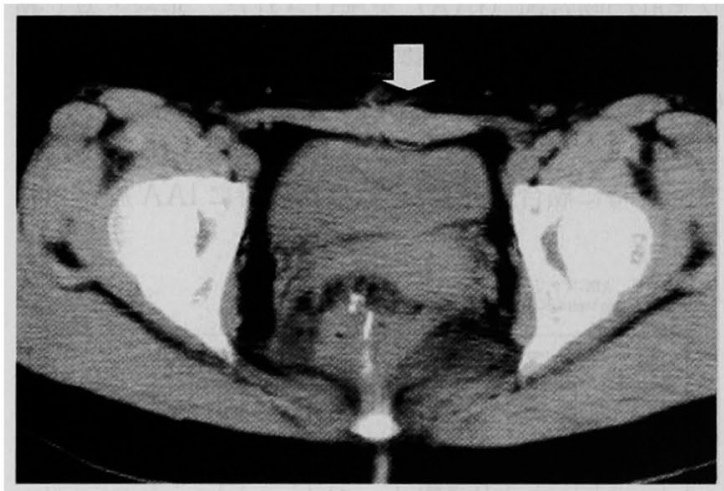

図 31 年前の CT 検查 (術後 1 年)：腹壁恥骨上前方にわ ずかに描出される病変（矢印）の存在が疑われる。

たが，下部直腸に癌 (深達度 $\mathrm{sm}$ ) 合併を認めた. APC 遺伝子検査では 2 人とも exon 15 (codon 658 1,283）に異常を認めた，家系にNF 1 とデスモイド腫 瘍はいない。

現病歴：平成10年 5 月に FAP の診断でIAA 施行 後, 定期的に当科外来へ通院していた。術後 1 年の上 部消化管内視鏡検查で十二指腸に多発腺腫が認めら

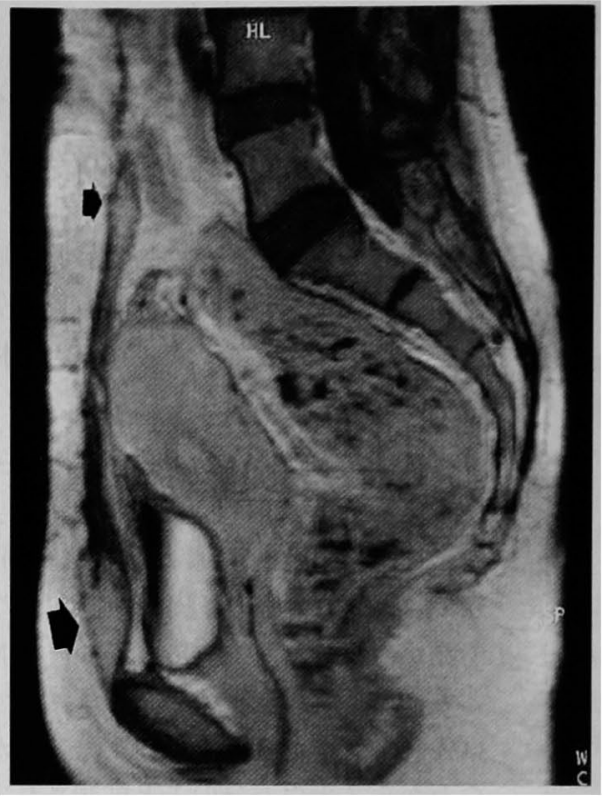

図 4 造影 MRI 矢状断面像：腹壁正中腹直筋 部に造影にてよく染まる頭側 $2 \mathrm{~cm}$ 大, 尾側 4 $\mathrm{cm}$ 大の 2 個の soft tissue tumor (矢印) があ り，頭尾側方向へ浸潤性であることを示して いる.

れ，その発癌予防目的に緑茶抽出物質の内服を開 (3)4), 腺腫の減少傾向を認めていた。術後 2 年のC 検查で下腹壁正中に 2 個の腫瘍を指摘された。それ での診察時触診では腫湯には気付かなかったが，そ ときの身体所見では腹壁正中臍下部に小指頭大・恥 上前方に鶏卵大の腫瘤を触知した。 Recklinghaus 病の合併があり FAP の術後であることより，デス イド腫瘍あるいは神経線維腫が疑われた。 また検査 見では，血液一般検查，生化学検查および腫愓マー 一に特記すべき所見を認めなかった，2力月後，M 検査施行し，デスモイド腫瘍または神経線維腫が疑 れたが診断確定には到らなかった。恥骨上前部の腫 から楔状生検を施行してデスモイド腫瘍との病理診 を得，1力月後に手術目的にて入院となった.

CT 検査所見：腹壁正中䏽下部レベル (図 2 上) と 骨上前方 (図 2 下) に，造影にてよく染まる腫瘤陰 を認めた。

1 年前(術後 1 年) の CT 検査所見（図 3 )：恥骨 前方部にわずかに描出される病変の存在が疑われた

MRI 検査所見：矢状断面像では,下腹壁正中腹直 部に頭側 $2 \mathrm{~cm}$ 大, 尾側 $4 \mathrm{~cm}$ 大の 2 個の腫瘍があり 頭尾側方向へ浸潤性であることを示している。また 


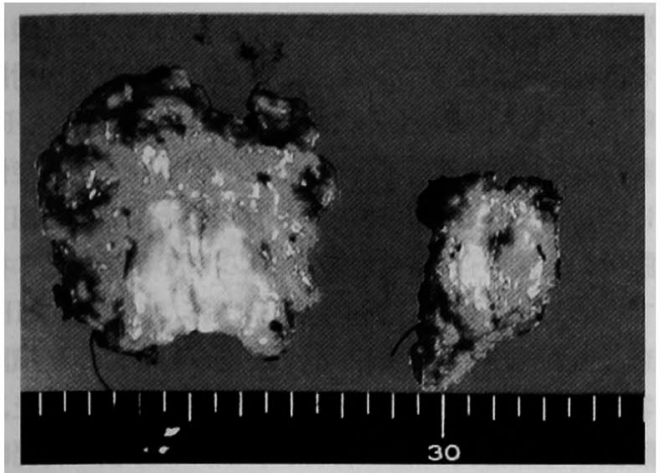

図 5 摘出標本：割面は充実性で灰白色を呈し，被 膜は認めない.

T 1 で low, T 2 で hetero ながら比較的 high, 造影(図 4）には比較的よく染まり dynamic curve での変化は 段階的に染まりが強くなる型であった。水平断面像で も矢状断面像と同様の所見であった。

手術所見：腫湯は 2 個とも前回の下腹部正中開腹創 の腹直筋層にあり，境界は不明瞭であったが，腹膜へ の露出は認めなかった。腫瘍は良性ではあるが局所浸 潤性が強く，遗残による局所再発の危険性が大きいの で,十分な切除断端を確保するように心がけ摘出した。 腹壁の欠損部は mesh を用いて修復した。

摘出肉眼摽本および病理組織学所見：摘出標本（図 5) の割面は充実性で灰白色を呈し，被膜は認めなか った. 組織学所見では，腫瘍中心部（図 6 上）で分化 した線維芽細胞と膠原㵶維の均一な増殖を示し，腫瘍 の辺縁部（図6下）では線維芽細胞の間に取込まれて 変性・萎縮に陥った骨格筋組織が認められ筋組織への 浸潤陽性であった。断端に腫場細胞は認めなかった。

\section{考 察}

神経線維腫症 (neurofibromatosis：NF) は, 全身 の皮居に多発する結節性病変と色素斑を特徵とする遺 伝性疾患として，1882年に Friedrich Daniel von Recklinghausenが本症を発表してから, Recklinghausen 病と呼ばれるようになった。その後, 両側性に 生じる聴神経腫瘍を主徵とする別の疾患が存在してい ることが明らかにされ，これを神経線維腫症 2 (NF 2) として区別するようになり，神経線維腫症 1 ( NF 1)についてのみ Recklinghausen 病の呼称が用いら れている. NF 1 の発生頻度は $3,000 〜 4,000$ 分の $1^{5 \text {, }}$, 国内患者数は約 4 万人と推定されている．遺伝形式は 常染色体優性で，浸透率は100\%である.NF 1 の 50〜70\%が自然突然変異による偶発例であり，半数以

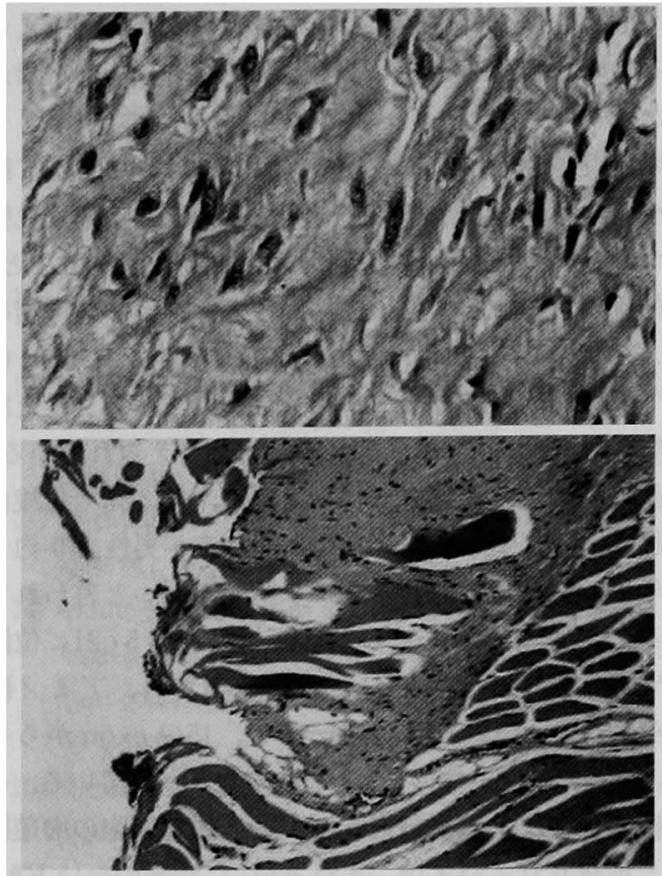

図 6 病理組織学所見：上）腫瘍中心部では分化し た線維芽細胞と膠原瀻維の均一な増殖を示す $(\mathrm{H}-$ $\mathrm{E} \times 400)$ ．下)腫瘍の辺緑部では線維芽細胞の間に 取込まれて変性・萎縮に陌つた骨格筋組織が認め られた $(\mathrm{H}-\mathrm{E} \times 100)$.

上の症例において両親は健常である．本症の突然変異 率は，新生児 10 万人あたり $4.3 \sim 4.9 \times 10^{-5}$ と高率であ る. NF 1 の主要街候は, 皮虙抽よび神経に生じる多発 性の神経線維腫，カフェ・オ・レ斑や小 Recklinghausen 斑などの色素斑,ならびに虹彩小結節で,そのほ かにも多彩な臨床症状（骨変化，視神経膠腫，脳脊䯚 神経腫瘍, 軽度の知能障害など）を呈する，患者の年 齢, 個々の症例によって, その症候や程度は著しく異 なり，社会生活に支障をきたすような重度の障害をも つ患者は全体の $10 \%$ 程度と考えられている，予後に最 も関与する malignant peripheral nerve sheath tumor (MPNST) の合併率は $4 \%$ 程度であり, 生命的 予後は比較的よい疾患である. NF 1 遺伝子は第17染 色体長腕の17q11.2に座位することが1987年に明らか にされ，1990年にクローニングされたが6) 8)，巨大遺伝 子で合計 60 の exon が確認されている゙910)．また2,818 アミノ酸残基をコードし，そのタンパクはニューロフ イプロミンと命名されている. 当症例は家系に NF 1 患者はなく，幼少時よりカフェ・オ・レ斑を認め高校 時代に皮膚生検で NF 1 と診断されているが，他には 
臨床症状もなく比較的予後良好な突然変異例と考えら れる.また，当症例ではNF 1 遺伝子検查は行われなか った。

家族性腺腫性ポリポーシス（FAP）は，主として結 腸・直腸に100個以上の腺腫を発生し，また上部消化管 のポリープや消化管外病変 (骨腫, 網膜色素肥大など) を伴う疾患である。常染色体優性遺伝を示し，浸透率 $93.7 \%$ て , 発生頻度は7,646分の 1 から 23,790 分の $1^{11112)}$ ，国内患者数約3,000と推定されている.また家 族歴陽性は $56 \%$ で,箪一遺伝子疾患と考えられている。 25歳を超えると発癌率は $10 \%$ を超え，年 $3 \%$ で急峻に 増加する ${ }^{13)}$. 平均発癌年齢は女性の方が男性より約 6 年早く, 密生型は非密生型より約 6 年早いと言われて いる. 原因遗伝子の APC 遗伝子は染色体 5 q21に位置 し14)15)，癌抑制遗伝子てあると考えられ，アミノ酸 2,843をコードする巨大遺伝子で，15の exon からな ク, exon 15は全体の $2 / 3$ を占めるとされている。 そ の機能は上皮・結合組織などの普遍的な細胞の増殖抑 制と推測されている ${ }^{16}$. また APCに変異のない FAP も33\%存在する．当症例では，24歳時に手術を施行さ れたが, 非密生型の FAP で癌の合併はなく，十二指腸 に多発腺腫を合併し, APC 遺伝子検查で exon 15に異 常を認める症例であった. 父は非密生型の FAP で, 56 歳で癌合併死した. 姉も非密生型の FAP で, 26歳時に 手術施行されたが，下部直腸に癌の合併を認めた。 た，父も姉も APC 遺伝子の exon 15に異常を認める 症例であった。

デスモイド腫場は筋や筋膜から発生する比較的稀な 軟部組織腫瘍で良性で転移はしないが，浸潤性で，切 除後に局所再発しやすく aggressive neurofibromatosis あるいは治療困難症とも呼ばれている. 発生頻度は, 人口10万人に 2 5人てある. 発生部位 では，腹壁 $49 \%$, 腹壁外 $38 \%$, 腹腔内 $8 \%$ と報告され ているが ${ }^{177}$ ，FAP では大部分が腹壁・腹空内に発生す る. 発症原因は外傷，女性ホルモンとの関連，先天性 要因が疑われている ${ }^{18)}$. 腫瘍はゆっくり発育し無症状 のことが多く, 画像診断上, 超音波検查では微細で均 一性な腫瘍として，CT スキャンでは造影で周辺がよ く染まる腫晹の所見が得られる.MRIでは筋に比して T 1 で低信号, T 2 で低信号と高信号(腫場細胞増殖区 の強い部)の混在, 造影でよく染まることが特徵と言 われ，さらに頭尾側への浸潤が明瞙に描出され，腫瘍 の発育性の予測や切除範囲の決定に有用であると言わ れている ${ }^{19220)}$.このように画像診断上,かなりの精度で
確定猃断に近いものが得られるが，最終的には生検に よる病理診断が必要である。治療は，切除術・放射線 照射・化学療法・ホルモン療法が行われているが, 可 能ならぼ切除術が第一選択と考えられている．当症例 では, 術後 1 年の CT 検査で, 前回手術創の下腹部正 中腹壁に腫瘍の存在が疑われ, さらに 1 年後の CT 検 査で造影でよく染まる腫瘍が指摘された。 また，MRI 検査でも頭尾側への浸潤を示す所見が得られ，組織診 断て筋層への浸潤が確認された。そして画像診断上， 切除後 7 カ月再発を認めていないが, 切除後の再発時 期は平均1.4年と言われており ${ }^{211}$,十分な経過観察が必 要である.デスモイド腫煬の遺伝性については非遺伝 性とされ, 当症例でも家族歴を認めていないが, Eccles らは APC 遺云子の codon 1,924k突然変異を生じた hereditary desmoid disease の家系を報告してお

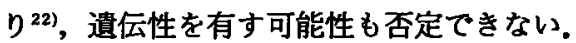

遺伝性癌症候群を決定する造伝子は100以上あり，そ のほとんどが常染色体優性に伝達され，そのなかで相

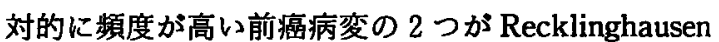
病と FAPである”。この 2 つは独立して遗伝するとさ れ，合併する確率は 2,300 万分の 1 から7,100万分の 1 であると推定されているが報告は世界でわずか 1 例で あり"，当症例は 2 例目の報告になると考えられる.

FAP とデスモイド腫湯の関係についての報告は多 数みられるが, FAP の 6〜13\%にデスモイド腫瘍が合 併すると言われ ${ }^{23)}$, APC 遺伝子変異とデスモイド尰場 との関連が示唆されている. APC 遺伝子変異のほとん どは codon 900〜1,600の間,特に codon 1,444以降に 発生し，デスモイド腫瘍の発現頻度が高くなると言わ れている2244. デスモイド腫瘍については exon 15に おける異常が多数報告されており 25) 27)，当症例におい ても exon 15 (codon 658 1,283) の異常を認めた. しかし, 父・姉も exon 15 (codon 658 1,283) に異 常を認めたがデスモイド腫場は合併していない,一方, APC 遺伝子の変異を有するが FAP のないデスモイ ド腫瘍もみられる.こうした事実は，巨大な APC 遺伝 子の変異の位置の差違が多様な発現の仕方に関与して いるものと推測されている28). また, 当症例では測定し ていないが，APC 遺伝子変異によって腫瘦でのベー タ・カテニン タンパク量の増加を認めることが知ら れている。このことは APC 遺伝子変異が核の機能を 介して腫煌細胞の増殖を起こしているのではないかと 考えられている291-31).

NF 1 とデスモイド腫瘍との関連については, 両疾 
患の合併の報告はみられるが32333)，遺伝子レベルでの 関係の有無についての報告はみられない。当症例では NF 1 を合併し，デスモイド腫場の合併に何らかの影 響を及ほした可能性はあるが，遺伝子レベルでの関連 性は不明であった。デスモイド腫瘍の遺伝性や NF 1 との関連性について,さらなる研究が必要と思われる.

\section{結 語}

Recklinghausen 病（NF 1）に次いで家族性腺腫性 ポリポーシス（FAP）を発症し，予防的大腸・直腸全 摘後にデスモイド腫瘍を合併した症例を経験し報告し た.

\section{文 献}

1) Lynch HT, Fitzgibbons RJ Jr, Lanapa JP, et al: Familial polyposis coli and neurofibromatosis in the same patient : a family study. Cancer Genetics and Cytogenetics $28: 245-251$, 1987

2) Caspari R, Olschwang S, Friedl $\mathrm{W}$, et al: Familial adenomatous polyposis: desmoid tumors and lack of ophtalmic lesions (CHRPE) associated with APC mutations beyond codon 1444. Human Molecular Genetics $4: 337-340$, 1995

3）石川秀樹：家族性腫瘍と発癌予防．癌と化療 $24: 951-957,1997$

4）山根哲郎：緑茶抽出物による消化器発癌の化学予 防. Mol Med 33:394-399, 1996

5) Riccardi VM : Von Recklinghausen's neurofibromatosis. N Engl J Med 305:1617-1627, 1981

6) Viskochil D, Buchberg AM, Xu G, et al : Deletions and a Translocation Interrupt a Cloned Gene at the Neurofibromatosis Type 1 Locus. Cell $62: 187-192,1990$

7) Cawthon RM, Weiss R, Xu G, et al : A Major Segment of the Neurofibromatosis Type 1 Gene:cDNA Sequence, Genomic Structure, and Point Mutations. Cell $62: 193-201,1990$

8) Wallace MR, Marchuk DA, Andersen LB, et al : Type 1 Neurofibromatosis Gene : Identification of a Large Transcript Disrupted in Three NF 1 Patients. Science 249 : 182, 1990

9) Li $\mathrm{Y}, \mathrm{O}^{\prime}$ Connell $\mathrm{P}$, Breidenbach $\mathrm{HH}$, et al : Genomic Organization of the Neurofibromatosis 1 Gene (NF1). Genomics 25:9-18,
1995

10) Danglot G, Regnier V, Fauvet D, et al : Neurofibromatosis 1 (NF1) mRNAs expressed in the central nervous system are differentially spliced in the 5 ' part of the gene. Hum Mol Genet 4: 915-920, 1995

11) Alm $T$, Licznerski $G$ : The intestinal polyposis. Clin Gastroenterol $2: 577-602,1973$

12) Veale AMO : Intestinal polyposis. In : Eugenics Laboratory Memoirs; XL, Cambridge University Press, London, 1965, p104

13）宇都宮讓二, 権藤延久, 吉川麗月 他：家族性腫瘍 の概念と意義. 外科 $58: 127-138,1996$

14) Bodmer WF, Bailey CJ, Bodmer J, et al : Localization of the gene for familial adenomatous polyposis on chromosome 5 . Nature 382 : 614616, 1987

15) Leppert $M$, Dobbs $M$, Scambler $P$, et al : The gene for familial polyposis coli maps to the long arm of chromosome 5 . Science $238: 1411$ $-1413,1987$

16）宇都宮譲二, 田村和朗，中村祐辅：家族性腺腫性 ポリポーシスの病熊と分子生物学的研究. 臨と研 $69: 80-88,1992$

17) Reitamo JJ, Hayry P, Nykri E: The desmoid tumor. I. Incidence, sex-, age and anatomical distribution in the Finnish population. Am J Clin Patho $77: 665-673,1982$

18) Hayry $P$, Reytamo JJ, Totterman $S$ : The Desmoid Tumor. II. Analysis of factors possibly contributing to the etiology and growth behavior. Am J Clin Patho 77:674-680, 1982

19）田中寿一, 三好新一郎, 藤井義敬他：切除範囲の 評価に MRI が有効であった左胸腹壁テスモイド 腫ようの1手術例. 日呼外会誌 $13: 58-62,1999$

20）小牧久和子, 奥佳世子, 今井茂樹他：画像診断亏 イブラリー腹腔, 腹壁のデスモイド腫矈の MRI と組織像の対比. 日医新報 $3923: 69-72,1999$

21) Pritchard DJ, Nasciment AG, Petersen IA : Local control of extra-abdominal desmoid tumors. J Bone Joint Surg Am 78: 848-854, 1996

22) Eccles DM, van der Luijt $R$, Breukel $C$, et al : Hereditary desmoid disease due to a frameshift mutation at codon 1924 of the APC gene. Am $\mathrm{J}$ of Human Genetics 59 : 1193-1201, 1996 
23) Ramos $R$, Carrel A, Herrera L: Chapter 17 Current treatment of desmoids in familial adenomatous polyposis patients. Ed. by Herrera L, Alan R. Familial adenomatous polyposis. Liss Inc, New York, 1990, p133-146

24) Clark SK, Phillips RK: Desmoids in familial adenomatous polyposis. British J of Surg 83 : 1494-1504, 1996

25) Gardner RJ, Kool D, Edkins E, et al : The clinical correlates of 3' truncating mutation (codons 1982-1983) in the adenomatous polyposis coli gene. Gastroenterology 113 : 326-331, 1997

26) Scott RJ, Froggatt NJ, Trembath RC, et al : Familial infiltrative fibromatosis (desmoid tumors) (MIM 135290) caused by a recurrent 3' APC gene mutation. Hum Mol Genet 5 : 19211924,1996

27) Nugent KP, Phillips RK, Hodgson SV, et al: Phenotypic expression in familial adenomatous polyposis : partial prediction by mutation analysis. Gut 35 : 1622-1623, 1994

28) Couture J, Mitri A, Lagace $R$, et al : A germline mutation at the extreme 3' end of the APC gene results in a severe desmoid phenotype and is associated with overexpression of beta-catenin in the desmoid tumor. Clinical Genetics $57: 205$ $-212,2000$

29) Tejpar S, Nollet F, Li C, et al : Predominance of beta-catenin mutations and beta-catenin dysregulation in sporadic aggressive fibromatosis (desmoid tumor). Oncogene 18 : $6615-6620,1999$

30) Miyosi $Y$, Iwao K, Nawa G, et al : Frequent mutations in the beta-catenin gene in desmoid tumors from patient without familial adenomatous polyposis. Oncology Research $10: 591-594,1998$

31) Alman BA, Li C, Pajerski ME, et al : Increased beta-catenin protein and somatic APC mutations in sporadic aggressive fibromatoses (desmoid tumors). Am J of Pathology $151: 329-$ 334, 1997

32) Mih $\mathrm{AD}$ : Desmoid tumor of the ulna in a patient with neurofibromatosis. $\mathrm{J}$ of Hand Surg $20: 1007-1010,1995$

33) Liebhart $M:$ Deep fascicular fibromatoses in diagnostic material from the pathomorphology department of the Institute of Mother and Child. Patologia Polska 40 : 159-169, 1989

\title{
A CASE OF ABDOMINAL WALL DESMOID TUMOR FOLLOWING PANCOLOPROCTECTOMY FOR FAMILIAL ADENOMATOUS POLYPOSIS WITH VON RECKLINGHAUSEN'S DISEASE
}

\author{
Isao OHORI, Makoto SASAKI, Tomoharu MIYASHITA, \\ Ken ASANO and Tatsuya KIMOTO* \\ Departments of Surgery and Radiology*, Kanazawa Red Cross Hospital
}

A 26-year-old woman developed abdominal wall desmoid tumor 2 years after undergoing a total coloproctectomy for familial adenomatous polyposis (FAP) with von Recklinghausen's disease. CT scan showed two tumors in the lower abdominal wall. Magnetic resonance imaging (MRI) confirmed the presence of two tumors in the lower sections of the abdominal wall. Histopathological diagnosis of a wedge biopsy revealed desmoid tumor. These tumors were removed in August 2000. Desmoid tumor is aggressive and very frequently recurs, but the patient has been free from recurrence, as of seven months after the surgery.

The incidence of von Recklinghausen's disease is approximately one in $3,000 \sim 4,000$, whereas that of FAP is one in 7,646 23,790. The probability of a patient manifesting both disorders is the product of the frequency of each namely between one in $23,000,000$ and one in $71,000,000$. Only one case of von Recklinghausen's disease with FAP has been reported in the world literature. Here is reported the first case of von Recklinghausen's disease associated with FAP and desmoid tumor. 